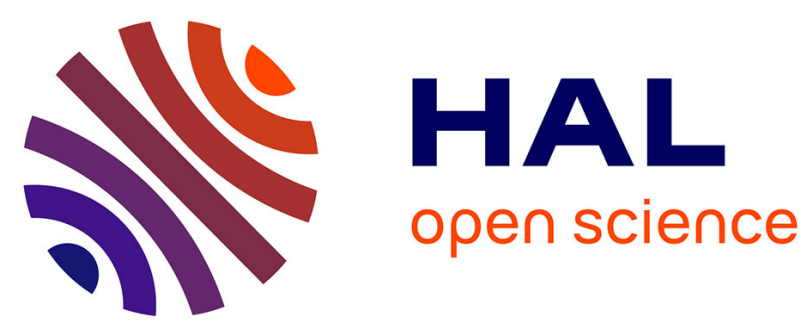

\title{
Avrami's law based kinetic modeling of colonization of mortar surface by alga Klebsormidium flaccidum
}

Thu Hien Tran, Alexandre Govin, René Guyonnet, Philippe Grosseau, Christine Lors, Denis Damidot, Olivier Devès, Bertrand Ruot

\section{- To cite this version:}

Thu Hien Tran, Alexandre Govin, René Guyonnet, Philippe Grosseau, Christine Lors, et al.. Avrami's law based kinetic modeling of colonization of mortar surface by alga Klebsormidium flaccidum. International Biodeterioration and Biodegradation, 2013, 79, pp.73-80. 10.1016/j.ibiod.2012.12.012 . hal-00804718

\section{HAL Id: hal-00804718 https://hal.science/hal-00804718}

Submitted on 26 Mar 2013

HAL is a multi-disciplinary open access archive for the deposit and dissemination of scientific research documents, whether they are published or not. The documents may come from teaching and research institutions in France or abroad, or from public or private research centers.
L'archive ouverte pluridisciplinaire HAL, est destinée au dépôt et à la diffusion de documents scientifiques de niveau recherche, publiés ou non, émanant des établissements d'enseignement et de recherche français ou étrangers, des laboratoires publics ou privés. 


\title{
Avrami's law based kinetic modeling of colonization of mortar surface by alga Klebsormidium flaccidum
}

Thu Hien TRAN ${ }^{\mathrm{a}, \mathrm{b}, \mathrm{c}}$, Alexandre GOVIN ${ }^{\mathrm{a}}$, René GUYONNET ${ }^{\mathrm{a}}$, Philippe GROSSEAU ${ }^{\mathrm{a}}$, Christine LORS $^{\mathrm{b}, \mathrm{c}}$, Denis DAMIDOT ${ }^{\mathrm{b}, \mathrm{c}}$, Olivier DEVES $^{\mathrm{d}}$, Bertrand RUOT ${ }^{\mathrm{d}}$

a : Ecole Nationale Supérieure des Mines de Saint Etienne, SPIN-EMSE, CNRS:UMR5307, PROPICE, LGF, 158 cours Fauriel, F-42023 St-Etienne, France

${ }^{\mathrm{b}}$ : Université Lille Nord de France, 1 bis Georges Lefèvre, F-59044 Lille, France

c: Ecole Nationale Supérieure des Mines de Douai, LGCgE-GCE, 941 Rue Charles Bourseul, F-59508 Douai, France

d: Université Paris Est, Centre Scientifique et Technique du Bâtiment, Département Enveloppe et Revêtements, 84 avenue Jean Jaurès, Champs-sur-Marne, F-77447 Marne-la-Vallée, France

$\begin{array}{ll}\text { Nomenclature } \\ \mathrm{X}(\mathrm{t}) & \text { colonization rate }(\%) \\ \mathrm{t} & \text { time (day) } \\ \mathrm{t}_{1} & \text { latency time (day) } \\ \gamma & \text { number of algal spots at time t per unit area } \\ \mathrm{d} \gamma / \mathrm{dt} & \text { specific attachment rate }\left(\mathrm{Spot} / \mu \mathrm{m}^{2} . \text { day) }\right. \\ \mathrm{S} & \text { surface of an algal spot }\left(\mu \mathrm{m}^{2}\right) \\ \mathrm{k}_{\mathrm{g}} & \text { specific attachment constant }\left(\mathrm{Spot} / \mu \mathrm{m}^{2} \cdot \mathrm{day}^{2}\right) \\ \mathrm{k}_{\mathrm{c}} & \text { growth rate constant }(\mu \mathrm{m} / \mathrm{day}) \\ \mathrm{K} & \text { overall rate constant }\left(\mathrm{Spot} / \mathrm{day}{ }^{4}\right) \\ \mathrm{n} & \text { Avrami's exponent }\end{array}$

\begin{abstract}
The aim of this research was to modelize the colonization of mortar surface by green algae using Avrami's law. The resistance of mortars, with different intrinsic characteristics (porosity, roughness, carbonation state), to the biofouling was studied by means of an accelerated lab-scale test. A suspension of green alga Klebsormidium flaccidum, was performed to periodically sprinkle the mortar surfaces. The covered surface rate followed a sigmoidal type curve versus time. Moreover, in order to apply Avrami's law, the algal colonization has been described by two processes: attachment and growth of algal cells. The image analysis showed that both the roughness and the carbonation influenced the algal attachment, unlike the porosity. The attachment specific rate increased linearly with time. For the algal growth process, it's difficult to conclude on the influence of mortar characteristics due to a high dispersion of experimental results. However, the assumption of a constant growth rate was acceptable. A good agreement between the simulation and the experimental results was obtained.
\end{abstract}

Keywords: modeling, Avrami’s law, biological colonization, algae, mortar

\section{Introduction}


The building facades, after construction, are inevitably subject to the colonization by microorganisms which can induce an aesthetical degradation of the construction. These microorganisms may be bacteria, algae, cyanobacteria, fungi, lichens and even higher plants if no prevention is achieved. It is found that, except ubiquitous bacteria, algae are the first colonizers. Moreover, the Klebsormidium flaccidum algae are well known for their wide distribution (John 1988; Ortega-Calvo et al. 1991 ; Ortega-Calvo et al. 1993 ; Gaylarde and Gaylarde 2000 ; 2005 ; Crispim et al. 2003 ; Rindi et al. 2008) and like being the dominant microorganism in biofilm composition (Barberousse et al. 2006). The biological biofouling causes an aesthetic problem and thus a significant economic loss due to the maintenance and the repair of the facades.

The implantation of microorganisms depends on various-origins parameters. Indeed, under temperate or tropical climate, the composition of a biofilm and the dominant species are respectively different (Crispim et al. 2003). According to several authors the microclimate (i.e. light, moisture) is an essential parameter which controls the nature and the growth of the microorganisms (John 1988; Ariño et al. 1997). The microclimate is influenced by the inclination, the orientation, the distance from ground and the exposure to the shadow of a building facade. The substrate characteristics, such as porosity, surface roughness, chemical composition and surface $\mathrm{pH}$, are obviously important (Deruelle 1991 ; Ortega-Calvo et al. 1995 ; Tomaselli et al. 2000 ; Tran et al 2012). Several authors showed that the biological colonization is faster on a rough wall (Wee and Lee 1980 ; Pietrini et al. 1985 ; Joshi and Mukudan 1997 ; Tomaselli et al. 2000 ; Tran et al. 2012). According to these authors, the roughness promotes the attachment of biological cells by providing numerous asperities. Moreover, a high porosity increases the amount of water available to microorganisms and thus favors their development (Ohshima 1999; Prieto and Silva 2005 ; Miller et al. 2006 ; Miller et al. 2009). On the contrary, the settlement by algae is slowed down or inhibited if the surface $\mathrm{pH}$ is greater than 11 (Grant 1982).

Several studies focused on the influence of these parameters on biofouling, at laboratory scale as well as at real scale. However, to our knowledge, very few studies have attempted to model this phenomenon. Ruot and Barberousse (2007) proposed a simulation of the surface materials colonization by algae. They showed that the Avrami's equation was quite a good tool to express the temporal evolution of the colonization rates. However, their study remains still preliminary and does not allow explaining the kinetic process and the role of material intrinsic characteristics.

Avrami's law, in the form of an exponential equation, has been developed by Avrami, Johnson and Melh for over 70 years (Avrami 1939; 1940 ; 1941 ; Johnson and Mehl 1939). This law was originally intended to describe the allotropic phase transformation in solids. Nowadays, it is used in many domains: crystallization of polymers, heat treatment in industry and thermal decomposition of solids ... (Hay 1971; Slovácek 2004). Avrami's model is based on two processes: the nucleation and the growth. The nucleation corresponds to the appearance of nuclei of a new phase. The growth represents the increase in the size of these nuclei into the initial phase during time.

In the case of this work, the fouling is initiated by the attachment of algae on the surface of the samples which creates many spots. The colonization rate follows a sigmoidal curve for the surface fraction colonized as function of time. As a consequence, colonization can be simulated thanks to the Avrami's model considering the algal spots as nuclei. Indeed, the algal spots are very small and randomly distributed on the surface. The extension of the fouling results from the increase in the size of the first algal spots by the growth of algal filament and from the adhesion of new spots as a function of time. 
The aim of this study is to modelize the colonization mechanism of the surface materials by algae using Avrami's model.

\section{Materials and methods}

The studied materials were mortars made up of Portland cement CEM I 52.5 N (Holcim), siliceous sand (Sibelco DU 0.1/0.35) and calcareous filler (Omya). Table 1 gives the proportions of each constituent. The mortar was prepared with a water to cement ratio w/c (wt./wt.) of 0.5. In order to obtain a more porous mortar, the w/c ratio was increased to 1 . However, cellulose ether (Hydroxylethyl Methyl Cellulose - HEMC) was added as admixture to thicken the mortar and thus avoiding segregation.

For each mortar, three finishing methods were applied on the surface of samples during the setting. One corresponded to a smoothing by a ruler and the two other to a scratching by sponges of two different roughnesses.

The mortar mixture was cast into $50 \times 50 \times 1 \mathrm{~cm}$ expanded polystyrene moulds and stored at $21 \pm 1{ }^{\circ} \mathrm{C}$ and $95 \pm 5 \%$ of relative humidity (RH) during 28 days (for the preparation of uncarbonated mortars). To prepare carbonated samples, the mortars were stored only 7 days before being cut into $20 \times 8 \times 1 \mathrm{~cm}$ samples. These samples were then stored in a chamber under pure $\mathrm{CO}_{2}$, at $21 \pm 1{ }^{\circ} \mathrm{C}$, and $65 \pm 5 \%$ relative humidity during 36 days.

The total porosity of materials was determined by mercury intrusion porosimetry (Micromeritics Autopore IV 9400). For each mortar, three samples beforehand dried by acetone were analyzed.

The surface roughness was measured using a CHR-150-L profilometer and was evaluated by the arithmetic average of the height $\left(\mathrm{R}_{\mathrm{a}}\right)$ (Gadelmawla et al. 2002).

The surface $\mathrm{pH}$ of mortars was measured by a surface electrode (WTW Sentix Sur). To ensure contact between the substrate and the $\mathrm{pH}$-electrode, a drop of water was deposed on the surface before measurement.

The studied algal specie was Klebsormidium flaccidum. It was chosen due to its representativeness and its facility of cultivation.

The bio-receptivity of mortar, depending on its characteristics (porosity, roughness, carbonation state), was examined through a laboratory accelerated test. The experimental device consisted of a $100 \times 50 \times 50 \mathrm{~cm}$ closed glass chamber placed in a dark room. At the beginning of the experiments, 50 L of sterilized Bold's Basal Medium (BBM) (Barberousse 2006) were inoculated with $K$. flaccidum in order to obtain an algal suspension of $4 \mathrm{mg} . \mathrm{L}^{-1}$ of dry mass. The algal growth was carried out at $24{ }^{\circ} \mathrm{C}$ by means of a thermo-regulator. In this device, two rows of samples were placed back to back on a stainless steel support inclined at $45^{\circ}$. Each row of samples was equipped with a system constituted of a stainless steel tube (10 $\mathrm{mm}$ diameter drilled every $10 \mathrm{~mm}$ ) and two pumps (Rena Flow $650 \mathrm{BF}$ ). This device allowed to the algal suspension, to flow on the top of each sample.

The sprinkling period and the flow rate were set respectively at 90 min every $12 \mathrm{~h}$ and at

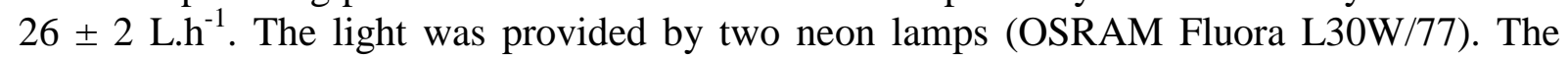
photoperiod was of $12 \mathrm{~h}$ and was starting with the beginning of a sprinkling cycle. 
In each test, 18 samples of materials were placed into the chamber. Each formulation was tested in triplicates. Carbonated or uncarbonated samples were tested separately.

Table 2 gives the characteristics of the studied mortars. Each mortar was labeled

\section{Theoretical basis of the model}

An example of biodeterioration result is shown on Fig. 1a. On this figure, the effect of the roughness on the biofouling of mortars by algae is highlighted for the mortar serie 10C (10 and $\mathrm{C}$ mean a w/c equal to 1 and carbonated, respectively). In fact, whatever the mortars studied, the shape of the curve, $\mathrm{X}(\mathrm{t})$, was always the same: sigmoidal type (Tran et al. 2012). In all cases, three steps were identified: a latency step, an exponential growth step and a step of stagnation (Tran et al. 2012). This type of curve can be well simulated by using Avrami's equation (Ruot and Barberousse 2007). As mentioned in the introduction, the Avrami's law is used to modelize the kinetics of allotropic phase transformations in solids. This model is based on two processes: the nucleation and the growth of nuclei. The nucleation corresponds to the formation of nuclei of a new phase. The growth corresponds to the increase in the size of these nuclei in the initial phase during time. However, the Avrami's law is only valid under the four assumptions below:

- the volume of the initial phase is unlimited compared to the nucleus one,

- the nuclei must be distributed randomly in the volume of the solid,

- the form and the growth of all the nuclei are identical,

- the growth rate is independent of the appearance time of the nucleus.

According to our biofouling results, an analogy between a chemical transformation and the fouling can be drawn. Thus it allows applying Avrami's theory. Indeed, during an allotropic transformation, the old phase is transformed into new one. In the case of the biological fouling of mortars, it is possible to consider the uncolonized mortar as the old phase and the mortar colonized by algae (algae attached on the surface of the mortar) as the new phase. In both cases, the transformation of the old phase into new one results from the displacement of the interface between both phases. Moreover, if we consider the algal biofouling of mortars, the curves $\mathrm{dX} / \mathrm{dt}=\mathrm{f}(\mathrm{X})$, such as those in Fig. 1b, exhibit a maximum. In the case of chemical reaction, such as thermal decomposition of solid, it suggests that the reaction involves simultaneous nucleation and growth processes of the new phase (Galwey 
and Brown). Kinetics modeling of these reactions are usually done using a general expression of the reaction rate under the form $\mathrm{dX} / \mathrm{dt}=\mathrm{A} . \mathrm{f}(\mathrm{X})$. A is a preexponential factor, which depends on temperature and activation energy and $f(X)$ a function of the fractional conversion $X$. When $X(t)$ is a sigmoidal curve, authors often use the Avrami laws to express $f(X)$. As it is shown on fig. $1 \mathrm{a}$, in our case, the colonization rate $\mathrm{X}(\mathrm{t})$ corresponds to a sigmoidal curve.

Moreover, the sample fouling is initiated by the attachment of algae on the surface of the samples. It results in the appearance of very small green spots on the surface, corresponding to algae, which can be assimilated to nuclei in the Avrami's model. The smaller algal spot detected by image analysis, i.e. one pixel, was about $7200 \mu \mathrm{m}^{2}$. This surface is very small compared to the samples size $\left(16010^{8} \mu \mathrm{m}^{2}\right)$. Thus the sample may be considered as infinite, as required by a two-dimensional Avrami's model. The thickness of algae biofilm was not investigated here.

The extension of the fouling results from the growth of the first algal spots and from the adhesion of new ones (Fig. 2). This confirms that the attachment and the growth occurred simultaneously, which allows the use of Avrami's model.

In addition, the algal spots appeared randomly on the sample surface as required by the Avrami's model.

Thus, the colonization by algae has been considered as the combination of two processes: the attachment and growth of algal spots, which were assimilated respectively to the "nucleation" step and to the growth step of the "nuclei" described in the Avrami's model.

To simplify the modeling, it was assumed that the attachment ("nucleation" in the Avrami's model) occurred with the same probability over the entire surface of the sample. As a consequence, the surface defects, such as air bubbles, did not affect the attachment of algae.

Fig. 1 showed that no colonization of the sample surfaces by algae occurred during several days. This time was called latency period. During this period the attachment and the growth of algae were null. The duration of this phase can depend on several parameters, such as sprinkling period, chemical composition of the specimen and of the culture medium... The latency time $\left(\mathrm{t}_{1}\right)$ was defined as the time corresponding to a colonization rate of $0.5 \%$. The best reproducibility was obtained using this method.

In general, the attachment and the growth of algae on the mortar surface might be affected by the porosity (p), the roughness (R), the initial $\mathrm{pH}$ of the surface (pH), the chemical composition of the mortar, the algae species, the algae viability, the light intensity, the temperature, the inclination of the substrate surface and the sprinkling flow. However, except the material properties (porosity, roughness and surface $\mathrm{pH}$ ), all other experimental parameters were constantly fixed.

The specific attachment rate was defined as the number of algal spots appearing on surface unit per time unit (eq.1).

$$
\frac{\mathrm{d} \gamma}{\mathrm{dt}}=\mathrm{k}_{\mathrm{g}}(\mathrm{p}, \mathrm{R}, \mathrm{pH}) \times\left(\mathrm{t}-\mathrm{t}_{1}\right)^{\mathrm{q}}
$$

Where:

$\gamma$ is the number of algal spots at time t per unit area $\left(\operatorname{Spot} / \mu \mathrm{m}^{2}\right)$.

$\mathrm{k}_{\mathrm{g}}$ is the attachment specific rate constant (Spot $\left./ \mu \mathrm{m}^{2} \cdot \mathrm{day}^{\mathrm{q}+1}\right)$.

$\mathrm{t}_{1}$ corresponds to the latency time (day). 
Concerning the growth, the hypotheses that the growth rate was identical for all algal spots and was constant during time were applied. The surface area covered by an algal spot appearing at time $\theta$ was expressed as follow:

$$
\mathrm{s}_{\mathrm{g}}(\mathrm{t}, \theta)=\mathrm{k}_{\mathrm{c}}^{2}(\mathrm{t}-\theta)^{2}
$$

251

252

253

Where $\mathrm{k}_{\mathrm{c}}$ corresponds to the specific growth rate constant ( $\mu \mathrm{m} /$ day).

$\mathrm{k}_{\mathrm{c}}$ takes into account the growth rate in each direction ( $\mathrm{x}$ and $\left.\mathrm{y}\right)$ and the form of the algal spot.

The colonization rate $\mathrm{X}(\mathrm{t})$ was calculated from the law of "nucleation" and growth previously expressed, as an exponential equation (eq. 3) (Delmon 1969).

$$
X(t)=1-e^{-K\left(t-t_{1}\right)^{n}}
$$

Where:

$$
\begin{aligned}
\mathrm{K} & =\mathrm{Ak}_{\mathrm{g}} \mathrm{k}_{\mathrm{c}}^{2} \\
\text { with } \quad \mathrm{A} & =\frac{2}{(\mathrm{q}+1)(\mathrm{q}+2)(\mathrm{q}+3)} \\
\mathrm{n} & =\mathrm{q}+3
\end{aligned}
$$

\section{Results}

\subsection{Experimental examination of algal attachment process}

The determination of the specific attachment rate of algae was carried out by the algorithm developed with Aphelion software. At each time step, new algal spots fixed on the surface were counted by image analysis. The specific attachment rate was thus calculated for each material by dividing the number of new algal spots per unit of time by the initial sample surface. The size of the smallest algal spot which could be detected was approximately $85 \times$ $85 \mu \mathrm{m}\left(7200 \mu \mathrm{m}^{2}\right)$. It corresponded to around 80 times the surface of an algal cell but only 4.5 $10^{-7}$ times the sample surface. This justified the hypothesis that the surface of the sample could be considered as infinite as required by the Avrami's model.

This process was applied only in the early stage where less than $8 \%$ of sample surface was covered by algae. A more advanced colonization disrupted the fixation of new algal cells and therefore distorted the determination of the specific attachment rate constant $\left(\mathrm{k}_{\mathrm{g}}\right)$.

\subsubsection{Influence of mortar characteristics on the algal attachment process}

Fig. 3 illustrates the evolution, during time, of the specific attachment rate of algae for carbonated mortars mixed with a w/c ratio of 1 . For each samples, the specific attachment rate is null during several days. This result confirms the existence of a latency period during which no spot is fixed to the surface. Moreover, despite important uncertainties, influence of the roughness on the algal attachment rate is obvious. Indeed, the rougher the mortar is, the higher the attachment rate is.

The effect of the carbonation of mortars (roughness R2 and w/c = 1), on the algal attachment rate is shown on Fig. 4. The attachment rate reached for the uncarbonated mortar is much smaller than for the carbonated one. 
For carbonated mortars and roughness $\mathrm{R} 2$, the influence of w/c ratio on the attachment rate is illustrated on Fig. 5. The results demonstrate that attachment specific rate for w/c ratios of 0.5 and 1 are very close. Thus, in our study, the effect of the porosity was negligible on the biofouling.

\subsubsection{Specific attachment rate constant}

According to the Figs. 3, 4 and 5, beyond the latency time, the specific attachment rate, which is equivalent to the "nucleation" rate in the Avrami's model, increases linearly with time. This result implies that the specific attachment rate can be modelized by a power law. In this case, the value of the power (q) is equal to 1 to express the attachment rate. Thus the specific attachment constant $\left(\mathrm{k}_{\mathrm{g}}\right)$ can be determined, beyond the latency time $\left(\mathrm{t}_{\mathrm{l}}\right)$, by a linear regression. Fig. 3 illustrates the fit obtained for carbonated mortars with a w/c ratio equal to 1 .

The values of $\mathrm{k}_{\mathrm{g}}$ for all the studied mortars are summarized in Table 3. For all the samples, to the exception of $05 \mathrm{R} 3-\mathrm{C}, \mathrm{k}_{\mathrm{g}}$ is strongly dependent of the roughness. Indeed, when the roughness increases, $\mathrm{k}_{\mathrm{g}}$ also increases. For example, $\mathrm{k}_{\mathrm{g}}$ of carbonated samples is 9 times higher and 30 times higher when the roughness increases from R1 to R2 and from R1 to R3 respectively.

The behavior of the 05R3-C sample for which the specific attachment constant was smaller than the one obtained for 05R2-C was particular. Despite a high $\mathrm{R}_{\mathrm{a}}$ value $(186 \mu \mathrm{m})$, the micro-roughness created by the sand grains was missing from the surface of these samples. This micro-roughness is important in promoting the algal adherence.

Moreover, beyond a roughness of $30 \mu \mathrm{m}$, the relationship between $\mathrm{k}_{\mathrm{g}}$ and the roughness $\left(\mathrm{R}_{\mathrm{a}}\right)$ seems to be linear (Fig. 6a). The slope of the straight line is around 4.6 and 0.7 respectively for the carbonated samples and the uncarbonated ones. So the carbonated samples are more sensitive to the roughness than uncarbonated ones.

In addition, the carbonation, and then the surface $\mathrm{pH}$, impacts the specific attachment constant. Indeed, whatever the roughness, $\mathrm{k}_{\mathrm{g}}$ is always higher for carbonated samples than for uncarbonated ones.

\subsubsection{Latency time}

The values of $t_{1}$ are summarized in Table 3. The latency time decreased with the roughness and the carbonation. For carbonated samples, the effect of the roughness is weak (fig. $6 \mathrm{~b}$ ). However, the effect is strongly marked with uncarbonated mortars.

Moreover, the latency time is really dependent of the chemical state of the surface. Indeed, the carbonation of the mortars decreases the latency time and thus increases the biocompatibility of the substrate. For example, the latency times range from 6 to 10 days for carbonated samples and from 17 to 44 days for uncarbonated ones.

\subsection{Experimental examination of growth process}

Image analysis and specific algorithm enabled us to locate and track changes, during time, of the surface of each algal spot found on the surface of the sample. The evolution of the spot surface corresponds to the growth of algae and thus to a growth rate.

The growth rate constant $\left(\mathrm{k}_{\mathrm{c}}\right)$ was experimentally determined and calculated according to the equation (7).

$$
k_{c}=\frac{\sqrt{S_{t+\Delta t}}-\sqrt{S_{t}}}{((t+\Delta t)-t)}
$$


Where:

$S_{t}$ represents the area of an algal spot at time $t\left(\mu \mathrm{m}^{2}\right)$

$\mathrm{S}_{\mathrm{t}+\Delta \mathrm{t}}$ represents the area of the same algal spot at time $\mathrm{t}+\Delta \mathrm{t}\left(\mu \mathrm{m}^{2}\right)$

Fig. 7 shows the evolution of $k_{c}$ with time for carbonated samples of $w / c$ ratio equal to 0.5 . The values of $\mathrm{k}_{\mathrm{c}}$ were determined for colonization rates below $50 \%$. Beyond this value, the number of algal spots that could be isolated to monitor their growth became too low. By considering the high dispersion of experimental results, the growth rate constant $\left(\mathrm{k}_{\mathrm{c}}\right)$ does not seem to vary significantly with time. This remark is also valid for all other mortars.

If the growth rate constant is considered as independent of time, the average of this constant could be calculated for each material. The results are presented on Fig. 8. Experimental errors were very important. It is therefore difficult to highlight the effect of intrinsic characteristics of materials on the growth rate constant. However, despite these uncertainties, it seems that, for each type of sample, the algal growth was lower on the uncarbonated samples than on the carbonated ones.

\subsection{Simulation of colonization rates}

In order to simulate the colonization process and in accordance with the results of paragraph 4.1.2, q was fixed to 1 and thus $\mathrm{n}$ was equal to 4 . The $\mathrm{K}$ parameter was adjusted from the equation (3) by the least squares method ( $\mathrm{K}$ was determined so that the error was minimal). In order to express the deviation between the model and experimental data, a fiability factor $(\mathrm{R})$ was calculated as follow:

Where:

$\mathrm{X}_{\mathrm{st}}$ represents the simulated colonization rate at time $\mathrm{t}$

$\mathrm{X}_{\mathrm{et}}$ represents the experimental colonization rate at time $\mathrm{t}$

All the values of $\mathrm{K}$ are summarized in the Table 3. As expected, $\mathrm{K}$ increases with the roughness and the carbonation with the exception of sample $05 \mathrm{C}-\mathrm{R} 3(\mathrm{w} / \mathrm{c}=0.5$, carbonated and high roughness). This result was previously described and discussed in paragraph 4.1.2. By using the equation (3) and the values of $\mathrm{K}$, it was possible to simulate the colonization rate. For all the carbonated mortars, the simulated curves were close to the experimental points (Fig. 9). The fiability factors were small with a maximum error lower than $11 \%$. For most of the uncarbonated mortars, a good agreement between simulated colonization rate and experimental data was obtained (Fig. 10). However, divergences can be noticed for the 10UC$\mathrm{R} 2$ serie (w/c=1, uncarbonated and intermediate roughness) which was not well simulated. Indeed, the fiability factor is equal to $25 \%$. However, as shown on fig. 10, these mortars exhibited abnormal behavior in our experiments.

\subsection{Comparison between the experimental and the calculated growth rate constant}


From the experimental values of $\mathrm{k}_{\mathrm{g}}$ determined by image analysis, the values of the growth rate constant ( $\left.\mathrm{k}_{\mathrm{c}-\mathrm{calculated}}\right)$ were calculated by the equation (9). Results obtained were compared with those experimentally determined.

$$
\mathrm{k}_{\mathrm{c}-\text { calculated }}=\sqrt{\frac{\mathrm{K}}{\mathrm{Ak_{ \textrm {g } }}}}
$$

393

As shown in Fig. 11, for all mortars, calculated values were higher than experimental ones. Except in the case of mortar 05UC-R1, for which the calculated value reached up 4 times the experimental one, the ratios between $\mathrm{k}_{\mathrm{c} \text {-calculated }}$ and $\mathrm{k}_{\mathrm{c} \text {-experimental }}$ were inferior to 3 for all the cases. Taking into account the uncertainties, the two values remained nevertheless close.

\section{Discussion}

In this paper, it was demonstrated that the Avrami's theory could be applied in order to simulate the colonization kinetic of mortar surfaces by algae, in an accelerated laboratory test. For almost all mortars, the simulated curves are very close to the experimental results. The nucleation-growth mechanism is well adapted to describe the phenomenon of biological colonization. Indeed, the colonization started by attachment of small algal spots (called "nuclei" in Avrami's law) and is extended by the growth of these latter. Each of these two processes was directly analyzed by image analysis.

The algal attachment on a surface is particularly complex, depending on several parameters such as the microorganism nature, the substrate type, the medium type, the microorganism concentration, which modify the interactions between the substrate and microorganisms and microorganisms themselves. However, in the case of this work, the mechanism of attachment was not studied. The author focused on the macroscopic aspect of the algal adhesion. Indeed, the size of the smallest area of algal spot which could be detected by image analysis was approximately $7200 \mu \mathrm{m}^{2}$. This area corresponded to around 80 times the surface of an algal cell. So, a spot is composed of a lot of algal cells. This spot concept integrates the complex phenomena involved in the adhesion of cells to a surface, the cell density and the surface properties which depend on metabolic activity and physiological state, necessary to retention and self-organization of cells (Carnazza et al. 2011).

The algal attachment on the sample surface was significantly influenced by the roughness. Indeed, roughness provides asperities, which promoted the anchorage of algal cells. It results in a higher specific attachment rate and a shorter latency time.

The carbonation, by decreasing surface $\mathrm{pH}$, favored the attachment and growth processes. It produced the same effects than the roughness, i.e. increasing the specific attachment rate and shortening the latency time. However, unlike the roughness which acts physically on the ability of algae to cling on a substrate, the carbonation may affect the algal metabolism. Indeed, in the case of carbonated mortars, the algal cells are in a less alkaline medium, and so, less stressful conditions than in the case of uncarbonated ones. The ability of attaching and spreading of algae on the surface are thus better for carbonated samples (Tran et al. 2012). The growth of the spots is the consequence of the vegetative or cellular multiplication which is favored at low $\mathrm{pH}$ (Škaloud, 2006).

The attachment of algae on the surface of the substrate is governed by adaptive metabolic interactions between algal cells and the substrate (Fattom et Shilo 1984, Finlay et al. 2002, 
Barberousse 2006). The algal extracellular polysaccharides can play the role of glue (Robins et al. 1986, Gantar et al. 1995, Barberousse 2006). These polymers are involved in the initial contact between the cell and the surface, and act over time (Barberousse 2006). Indeed, they exist permanently on the cell wall and are adsorbed on the surface in contact.

These metabolites are composed of hexoses (glucose, galactose, mannose), 6deoxyhexoses (rhamnose, fucose) and pentoses (xylose, arabinose). The main constituent depends on the algal species considered and the substrate. For Klebsormidium flaccidum, mannose was identified as the major component (Barbarosse 2006).

In contrast, the role of w/c ratio on the algal attachment was not detected. As mentioned by Tran et al. (2012), due to the test conditions, the mortars permanently contained abundant water. So this last was not a limited factor for the algal growth.

It was proved by image analysis that, in the early stage, algal specific attachment rate evolved linearly with time. In order to model the colonization rate (eq. (3)), it was supposed that the attachment rate increased linearly with time, throughout all the process.

The influence of intrinsic material characteristics on the growth process has not been shown due to important experimental uncertainties. The errors may result from the detachment of ancient cells or the adherence of new cells at the periphery of existing spots due to the periodic runoff. In these cases, the surface variation of spots was no longer only related to their growth. However, the assumption of constant growth rate over time was found acceptable.

The variation in algal activity between the different tests prevents us from generalizing the results. Thus, no general equation describing the relationship between the kinetic parameters $\left(\mathrm{t}_{\mathrm{l}}, \mathrm{k}_{\mathrm{g}}\right)$ and the intrinsic material parameters could be obtained.

\section{Conclusion}

The kinetic of biological colonization on mortar surface was well modelized in applying Avrami's theory. The experimental conditions used in this study were suitable for the application of the Avrami's model and satisfied to assumptions of the model. The model based on two steps, "nucleation" or attachment and growth, closely represents the colonization rate.

The influence of roughness and carbonation on the attachment frequency was highlighted. These two intrinsic parameters promoted the anchorage of algae on the substrate by increasing the attachment rate and by shortening the latency time. The porosity had no effect in our tests.

According to the results, the evolution of the attachment rate as function of time seems linear. So the attachment rate followed a powerful law with a power q equal to 1 .

Due to large experimental uncertainties, it was difficult to conclude on the growth rate of algal spots. However, supposition of a constant growth rate of spots appeared acceptable.

\section{References}

Ariño, X., Gomez-Bolea, A., Saiz-Jimenez, C., 1997. Lichens on ancient mortar. International Biodeterioration and Biodegradation 40, 217-224.

Avrami, M., 1939. Kinetics of phase change I - General Theory. Journal of Chemical Physics 7, 1103-1112.

Avrami, M., 1940. Kinetics of phase change II - Transformation-Time Relations for Random Distribution Nuclei. Journal of Chemical Physics 8, 212-224. 
Avrami, M., 1941. Granulation, phase change, and microstructure - Kinetics of phase change III. Journal of Chemical Physics 9, 177-185.

Barberousse, H., Tell, G., Yéprémian, C., Couté, A., 2006. Diversity of algae and cyanobacteria growing on building façades in France. Algological Studies 120: 83-110.

Carnazza, S., Marletta, G., Frasca, M., Fortuna, L., Guglielmino, S., 2011. Spatial patterns of microbial retention on polymer surfaces. Journal of Adhesion Science and Technology 25, 2255-2280

Crispim, C.A., Gaylarde, P.M., Gaylarde, C.C., 2003. Algal and cyanobacterial biofilms on calcareous historic buildings. Current Microbiology 46, 79-82.

Delmon, B., 1969. Introduction à la cinétique hétérogène. Ed. Technip, Paris.

Deruelle, S., 1991. Rôle du support dans la croissance des microorganismes. Materials and Structures 24, 163-168.

Fattom, A., Shilo, M., 1984. Hydrophobicity as an adhesion mechanism of benthic cyanobacteria. Applied and Environmental Microbiology 47, 135-143.

Finlay, J.A., Callow, M.E., Ista, L.K., Lopez, G.P., Callow, J.A., 2002. The Influence of Surface Wettability on the Adhesion Strength of Settled Spores of the Green Alga Enteromorpha and the Diatom Amphora. Integrative and Comparative Biology 42, 11161122.

Galwey, A.K., Brown, M.E., 1999 Thermal Decomposition of Ionic Solids, Elsevier, Netherlands.

Gantar, M., Rowell, P., Kerby, N.W., 1995. Role of extra- cellular polysaccharides in the colonization of wheat (Triticum vulgarie L.) roots by $\mathrm{N}_{2}$-fixing cyanobacteria. Biology and Fertility of Soils 19, 41-48.

Gaylarde,P.M., Gaylarde, C.C., 2000. Algae and cyanobacteria on painted buildings in Latin America. International Biodeterioration and Biodegradation 46, 93-97.

Gaylarde, C.C., Gaylarde, P.M., 2005. A comparative study of the major microbial biomass of biofilms on exteriors of buildings in Europe and Latin America. International Biodeterioration and Biodegradation 55, 131-139.

Grant, C., 1982. Fouling of terrestrial substrates by algae and implications for control - a review. International Biodeterioration Bulletin 18, 57-65.

Hay, J. N., 1971. Application of the modified avrami equations to polymer crystallisation kinetics. British Polymer Journal 3, 74-82.

John, D.M., 1988. Algal growth on buildings: A general review and methods of treatment. Biodeterioration Abstracts 2, 81-102.

Joshi, C.D., Mukunda, U., 1997. Algal disfigurement and degradation of architectural paints in India. Paintindia 47, 27-32.

Johnson, W.A., Mehl, R.F., 1939. Reaction Kinetics in Processes of Nucleation and Growth. Trans. Amer. Inst. Ming. Metall. 135, 416-458.

Miller, A., Dionísio, A., Macedo, M.F., 2006. Primary bioreceptivity: A comparative study of different Portuguese lithotypes. International Biodeterioration and Biodegradation 57, 136-142.

Miller, A.Z., Dionísio, A., Laiz, L., Macedo, M.F., Saiz-Jimenez, C., 2009. The influence of inherent properties of building limestones on their bioreceptivity to phototrophic microorganisms. Annals of Microbiology 59, 705-713.

Ohshima, A., Matsui, I., Yuasa, N., Henmi, Y., 1999. A study on growth of fungus and algae on mortar. Transactions of the Japan Concrete Institute 21, 173-178.

Ortega-Calvo, J.J., Hernandez-Marine, M., Saiz-Jimenez, C., 1991. Biodeterioration of building materials by cyanobacteria and algae. International Biodeterioration 28, 165-185. 
Ortega-Calvo, J.J., Sanchez-Castillo, P.M., Hernandez-Marine, M., Saiz-Jimenez, C., 1993. Isolation and characterization of epilithic chlorophytes and cyanobacteria from two Spanish cathedrals (Salamanca and Toledo). Nova Hedwigia 57, 239-253.

Ortega-Calvo, J.J., Ariño, X., Hernandez-Marine, M., Saiz-Jimenez, C., 1995. Factors affecting the weathering and colonization of monuments by phototrophic microorganisms. Science of The Total Environment 167, 329-341.

Pietrini, A.M., Ricci, M., Bartolini, M., Giuliani, M.R., 1985. A reddish colour alteration caused by algae on stoneworks. Proceedings of the Vth international congress on deterioration and conservation of stone, Presses polytechniques romandes, Lausanne, 653-662.

Prieto, B., Silva, B., 2005. Estimation of the potential bioreceptivity of granitic rocks from their intrinsic properties. International Biodeterioration and Biodegradation 56, 206-215.

Rindi, F., Guiry, M.D., López-Bautista, J.M., 2008. Distribution, morphology, and phylogeny of Klebsormidium (Klebsormidiales, Charophyceae) in urban environments in Europe. Journal of Phycology 44, 1529-1540.

Robins, R.J., Hall, D.O., Shi, D.J., Turner, R.J., Rhodes, M.J.C., 1986. Mucilage acts to adhere cyanobacteria and cultured plant cells to biological and inert surfaces. FEMS Microbiology Letters 34, 155-160.

Ruot, B., Barberousse, H. (2007). Quantification and kinetic modeling of the colonisation of façade rendering mortars by algae. VII SBTA, Recife, Brazil, 1-12.

Şkaloud, P., 2006. Variation and taxonomic significance of some morphological features in european strains of Klebsormidium (Klebsormidiophyceae, Streptophyta). Nova Hedwigia 83, 533-550.

Slovácek, M., 2004. Application of numerical simulation of heat treatment in industry. J. Phys. IV France 120, 753-760.

Tomaselli, L., Lamenti, G., Bosco, M., Tiano, P., 2000. Biodiversity of photosynthetic micro-organisms dwelling on stone monuments. International Biodeterioration and Biodegradation 46, 251-258.

Tran, T.H., Govin, A., Guyonnet, R., Grosseau, P., Lors, C., Garcia-Diaz, E., Damidot, D., Deves, O., Ruot, B., 2012. Influence of the intrinsic characteristics of mortars on biofouling by Klebsormidium flaccidum. International Biodeterioration and Biodegradation 70, 31-39.

Wee, Y.C., Lee K.B., 1980. Proliferation of algae on surfaces of buildings in Singapore. International Biodeterioration Bulletin 16, 113-117. 
Table 1. Mortar formulation

\begin{tabular}{lcccc}
\hline Component & Cement & Sand & Calcareous Filler & $\begin{array}{c}\text { Admixture }^{\mathrm{a}} \\
\text { (in the case of } w / \mathrm{c}=1)\end{array}$ \\
\hline $\begin{array}{c}\% \text { mass of dry } \\
\text { mixture }\end{array}$ & 30 & 65 & 5 & 0.27 \\
\hline in addition to dry mixture (cement, sand and filler)
\end{tabular}

Table 2. Characteristics of the mortars

\begin{tabular}{|c|c|c|c|c|c|c|}
\hline & Ratio w/c & Porosity (\%) & Surface $\mathrm{pH}$ & & Code & $\mathrm{R}_{\mathrm{a}}(\mu \mathrm{m})$ \\
\hline \multirow{6}{*}{ 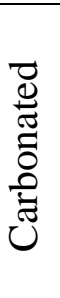 } & \multirow{3}{*}{0.5} & \multirow{3}{*}{$10.6 \pm 0.4$} & \multirow{3}{*}{$9.5 \pm 0.2$} & Roughness 1 & 05C-R1 & $40 \pm 9$ \\
\hline & & & & Roughness 2 & 05C-R2 & $90 \pm 8$ \\
\hline & & & & Roughness 3 & 05C-R3 & $186 \pm 21$ \\
\hline & \multirow{3}{*}{1.0} & \multirow{3}{*}{$32.1 \pm 1.9$} & \multirow{3}{*}{$9.0 \pm 0.1$} & Roughness 1 & 10C-R1 & $30 \pm 3$ \\
\hline & & & & Roughness 2 & 10C-R2 & $55 \pm 4$ \\
\hline & & & & Roughness 3 & 10C-R3 & $169 \pm 17$ \\
\hline \multirow{6}{*}{ 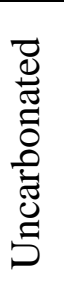 } & \multirow{3}{*}{0.5} & \multirow{3}{*}{$15.9 \pm 0.6$} & \multirow{3}{*}{$11.2 \pm 0.4$} & Roughness 1 & 05UC-R1 & $29 \pm 5$ \\
\hline & & & & Roughness 2 & 05UC-R2 & $47 \pm 6$ \\
\hline & & & & Roughness 3 & 05UC-R3 & $123 \pm 9$ \\
\hline & \multirow{3}{*}{1.0} & \multirow{3}{*}{$37.2 \pm 0$} & \multirow{3}{*}{$11 \pm 0.4$} & Roughness 1 & 10UC-R1 & $29 \pm 5$ \\
\hline & & & & Roughness 2 & 10UC-R2 & $55 \pm 4$ \\
\hline & & & & Roughness 3 & 10UC-R3 & $123 \pm 9$ \\
\hline
\end{tabular}

Table 3. Experimental and calculated kinetic parameters and fiability factor

\begin{tabular}{|c|c|c|c|c|c|c|c|}
\hline & Mortar & $\begin{array}{c}\mathbf{t}_{1} \\
(\text { day })\end{array}$ & $\begin{array}{c}\mathbf{k}_{\mathrm{g}}\left(\times 10^{10}\right) \\
\left(\mathrm{spot}^{\prime} / \mathrm{mm}^{2} . \mathrm{day}^{2}\right)\end{array}$ & $\begin{array}{c}\mathbf{k}_{\text {c-experimental }} \\
(\mu \mathrm{m} / \mathrm{day})\end{array}$ & $\begin{array}{c}\mathrm{K}\left(\times 10^{6}\right) \\
\left(\text { spot }^{6} \text { day }^{4}\right)\end{array}$ & $\begin{array}{c}\mathrm{R} \\
(\%)\end{array}$ & $\begin{array}{l}\mathbf{k}_{\text {c-calculated }} \\
(\mu \mathrm{m} / \mathrm{day})\end{array}$ \\
\hline \multirow{6}{*}{ 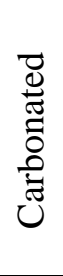 } & 10C-R1 & $10 \pm 2$ & 21.3 & $184 \pm 147$ & 22.3 & 5 & 299 \\
\hline & 10C-R2 & $8 \pm 1$ & 183.9 & $122 \pm 93$ & 193.6 & 7 & 350 \\
\hline & 10C-R3 & $6 \pm 1$ & 652.6 & $109 \pm 71$ & 437.9 & 7 & 285 \\
\hline & 05C-R1 & $9 \pm 2$ & 39.0 & $132 \pm 103$ & 36.2 & 11 & 337 \\
\hline & 05C-R2 & $8 \pm 1$ & 376.2 & $101 \pm 87$ & 492.5 & 10 & 298 \\
\hline & 05C-R3 & $8 \pm 2$ & 127.0 & $124 \pm 95$ & 76.4 & 8 & 263 \\
\hline \multirow{5}{*}{ 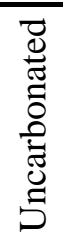 } & 10UC-R1 & $27 \pm 1$ & 1.5 & $74 \pm 68$ & 0.2 & 8 & 131 \\
\hline & 10UC-R2 & $20 \pm 1$ & 84.1 & $66 \pm 51$ & 1.5 & 25 & 103 \\
\hline & 10UC-R3 & $18 \pm 2$ & 86.3 & $83 \pm 57$ & 31.8 & 12 & 201 \\
\hline & 05UC-R1 & $44 \pm 5$ & 1.9 & $60 \pm 50$ & 0.7 & 8 & 237 \\
\hline & 05UC-R2 & $27 \pm 4$ & 8.4 & $74 \pm 47$ & 0.4 & 8 & 72 \\
\hline
\end{tabular}




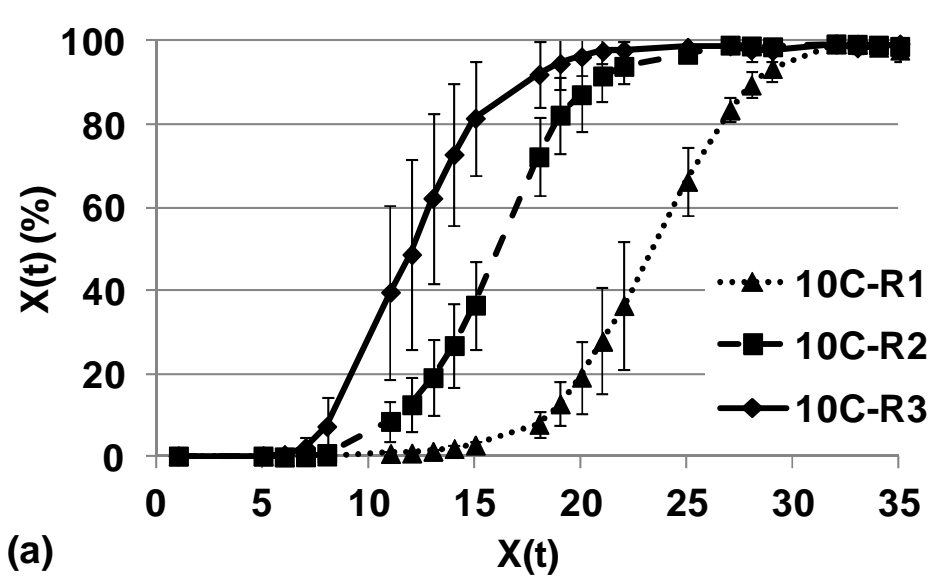

(b)

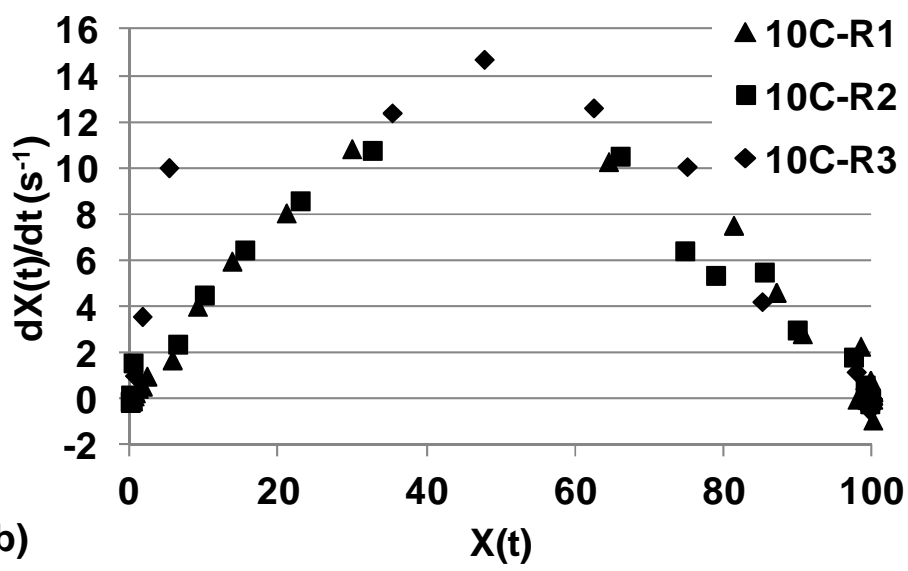

587 Fig. 1 Influence of roughness $(\mathrm{R} 1=30 \mu \mathrm{m}, \mathrm{R} 2=55 \mu \mathrm{m}$ and $\mathrm{R} 3=169 \mu \mathrm{m})$ on the algal biofouling 588 of carbonated (C) mortars with a w/c ratio equal to $1:$ a) $\mathrm{X}(\mathrm{t})$ and b) $\mathrm{dX}(\mathrm{t}) / \mathrm{dt}$ 


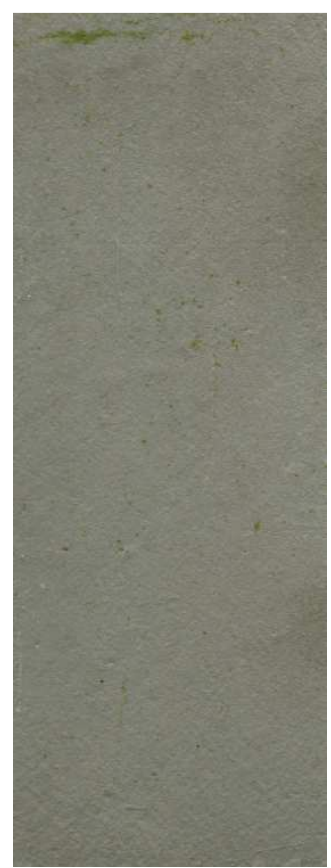

12 days

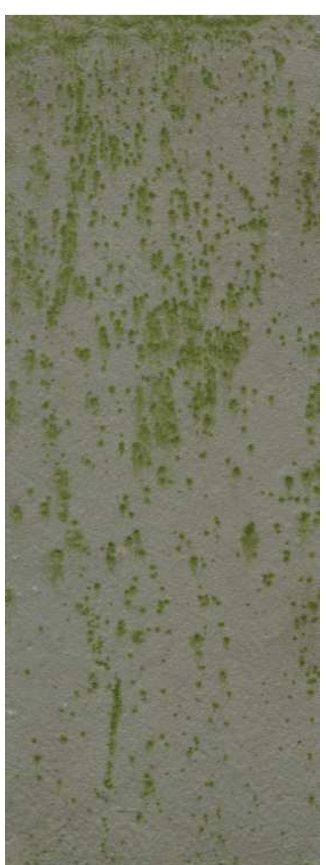

19 days

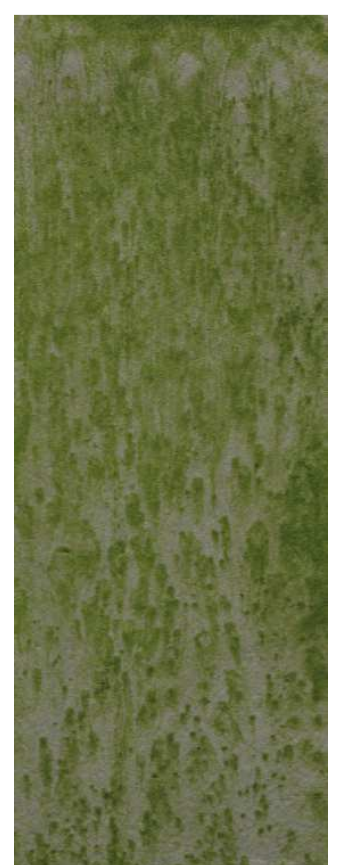

26 days

591 Fig. 2 Surface of carbonated mortars with a w/c ratio of 0.5 and a roughness R1, colonized by 592 algae over time 593 


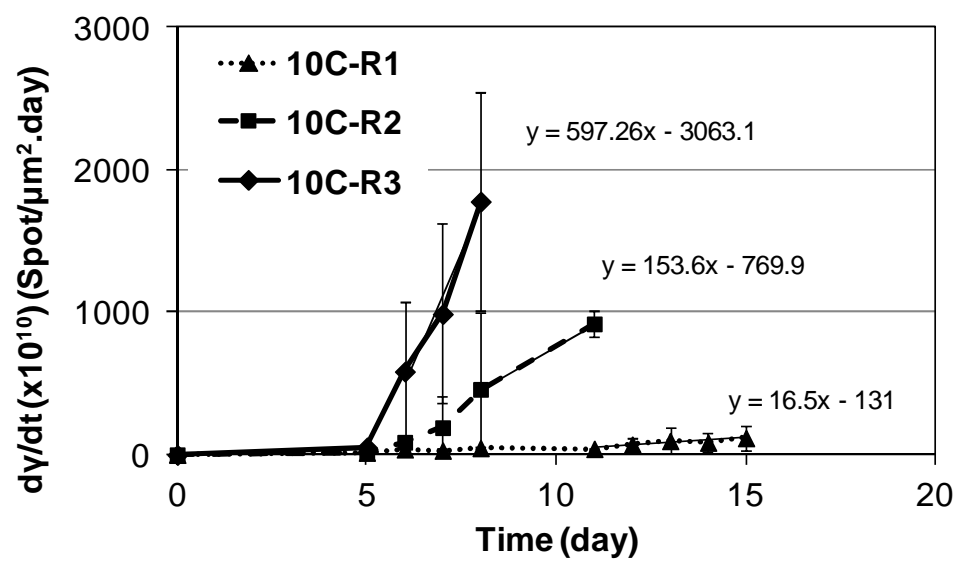

595

Fig. 3 Influence of the roughness (R1, R2 and R3) on the specific attachment rate of algae 596 (specifications of mortars: carbonated (C) and w/c ratio of 1) 


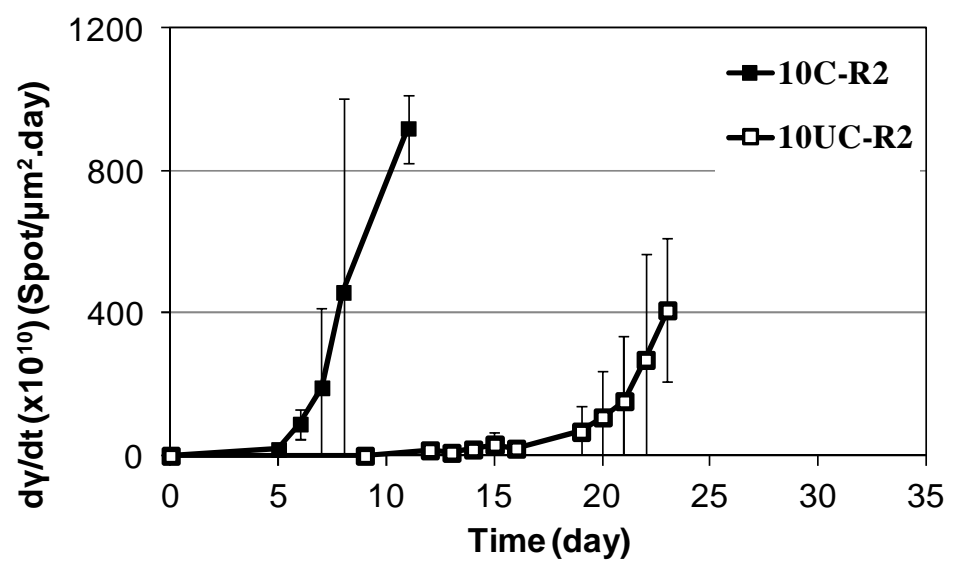

600

Fig. 4 Influence of the carbonation state (C for carbonated and UC for uncarbonated) on 602 the specific attachment rate of algae (specifications of mortars: intermediate roughness (R2), 603 w/c ratio of 1 )

604 


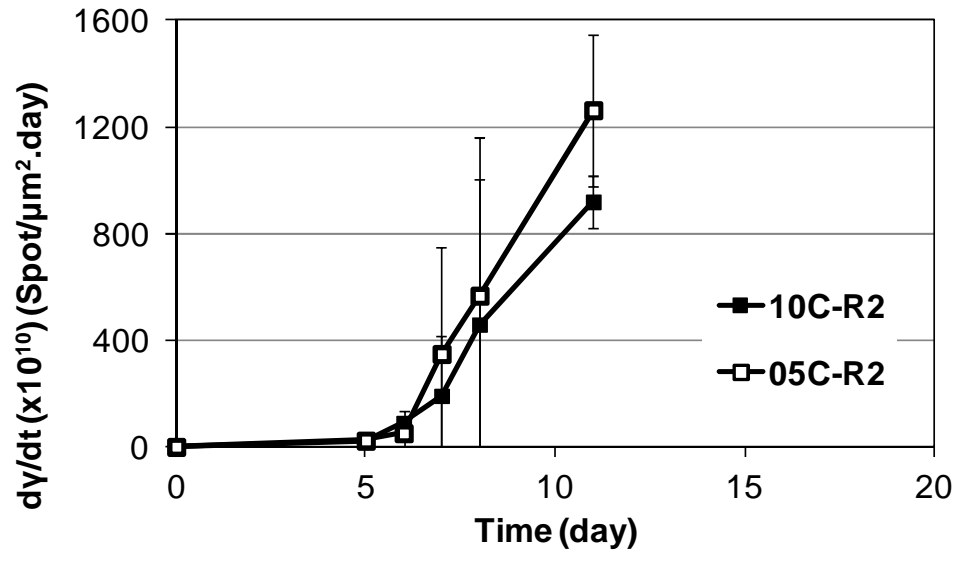

607 Fig. 5 Influence of the w/c ratio on the specific attachment rate of algae (specifications of 608 mortars: carbonated (C) and intermediate roughness (R2))

609 
611
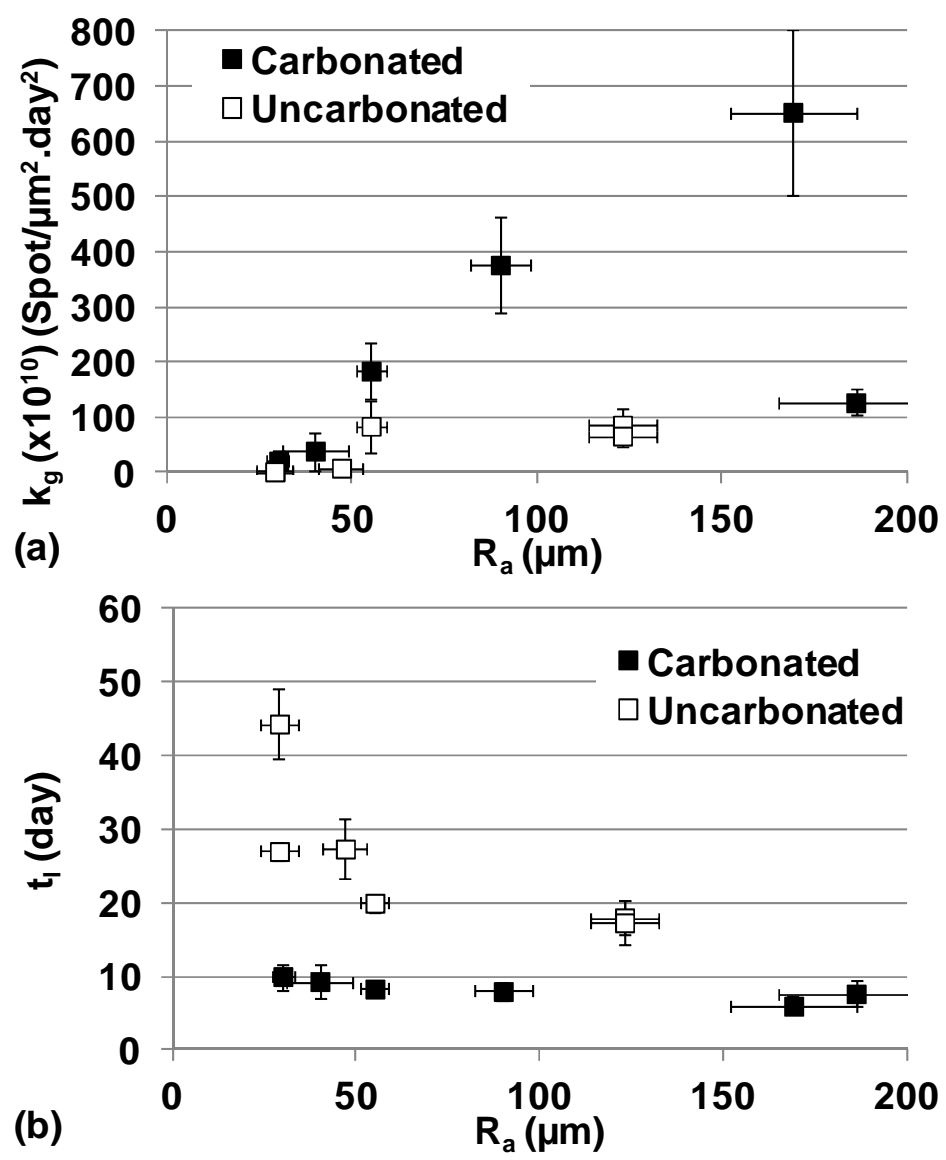

613 Fig. 6 Effect of roughness $\left(R_{a}\right)$ on the specific attachment constant (a) and on the latency 614 time (b) for carbonated (C) and uncarbonated (UC) mortars 615 


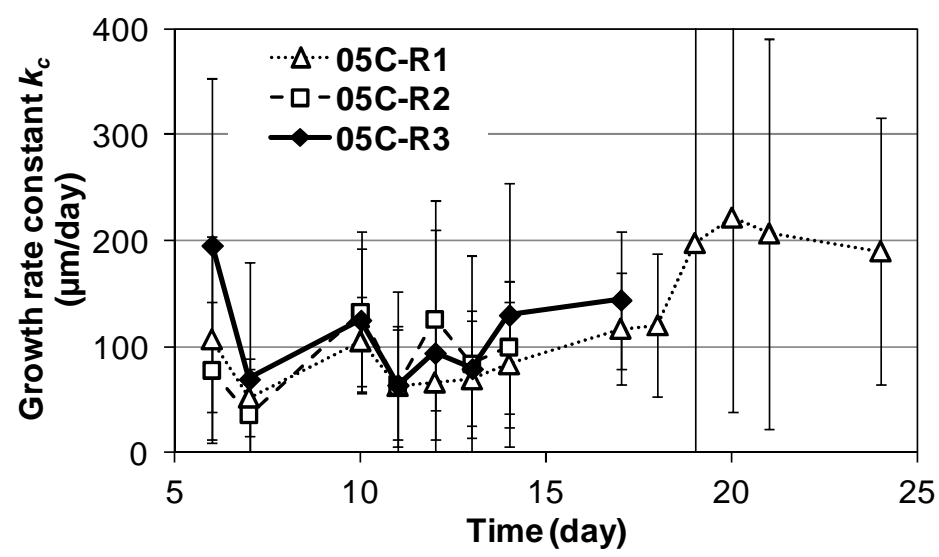

617

618

Fig. 7 Influence of roughness (R1, R2 and R3) on the growth rate constant versus time 


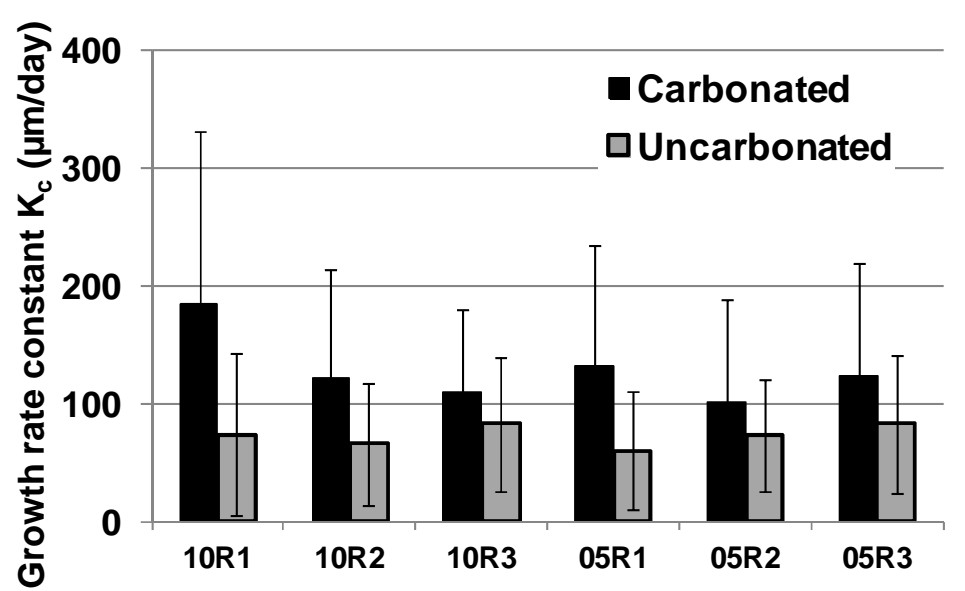

623

Fig. 8 Average of the growth rate constant for all the studied samples 624 


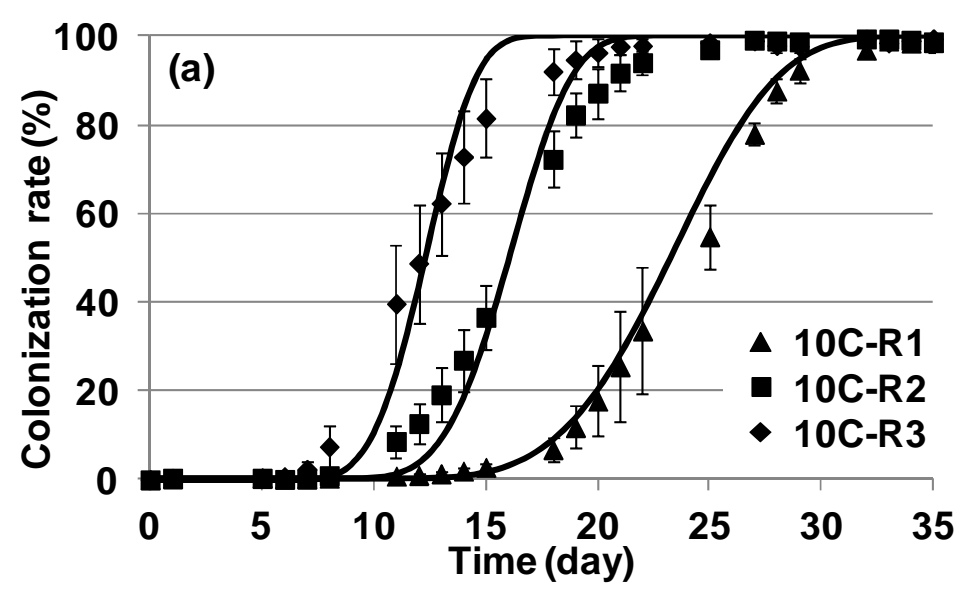

626

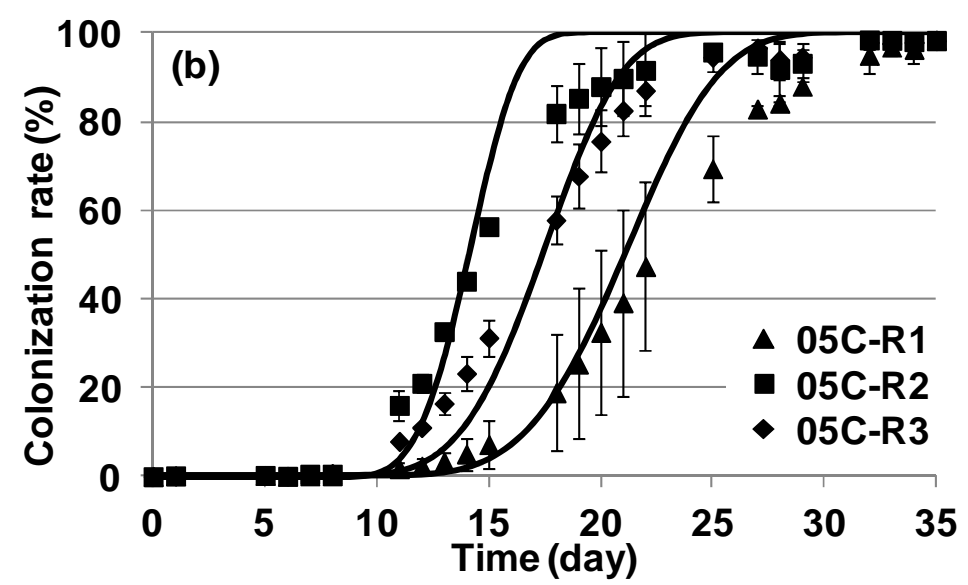

627

628 Fig. 9 Simulation of colonization rate for carbonated mortars mixed with w/c ratio of 1 (a) and 629 0.5 (b) (points: experimental data; lines: simulation)

630 

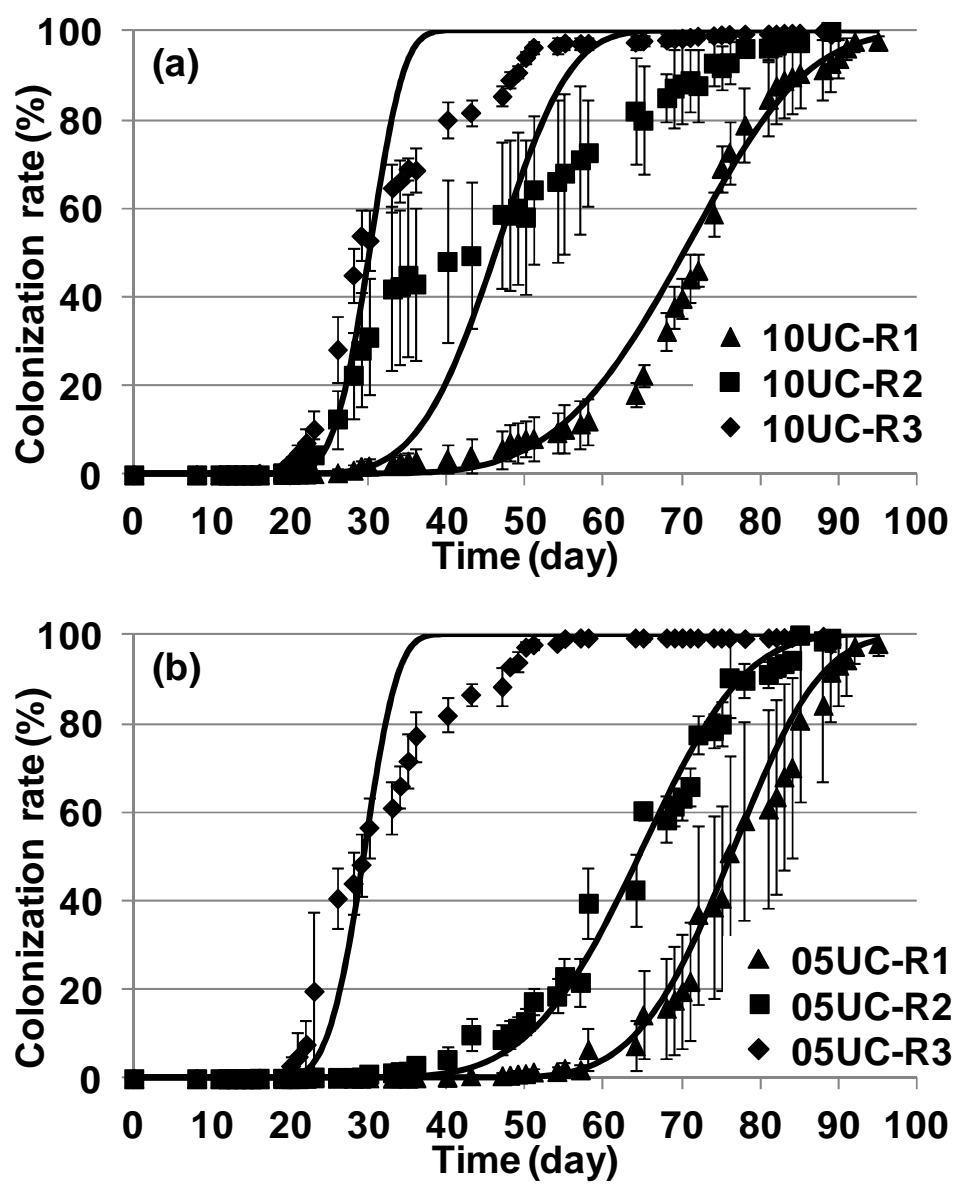

633

Fig. 10 Simulation of colonization rate for uncarbonated mortars mixed with w/c ratio of (a) and 0.5 (b) (points: experimental data; lines: simulation)

635 (a) and 0.5 (b) (points: experimental data, lines: simulation)

636 


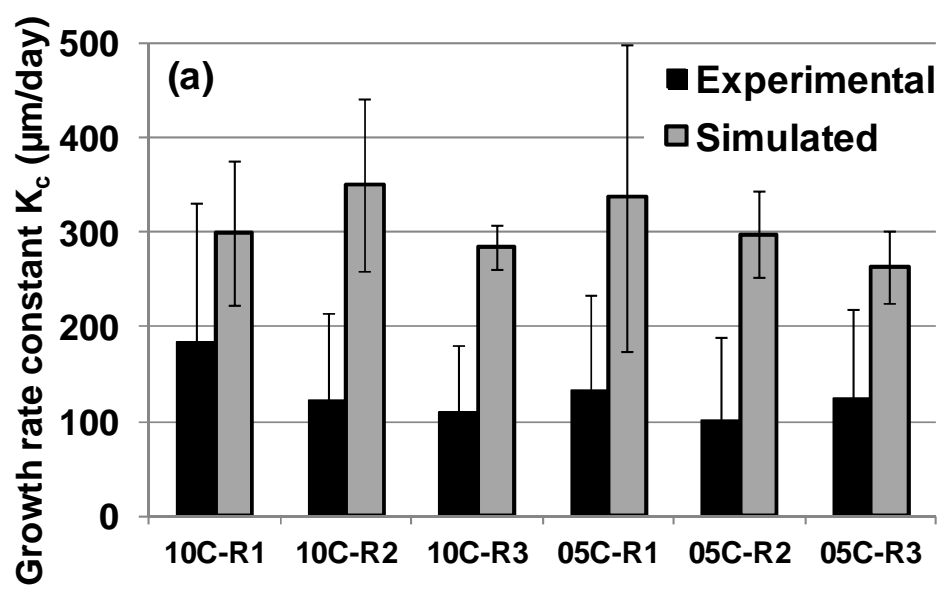

639

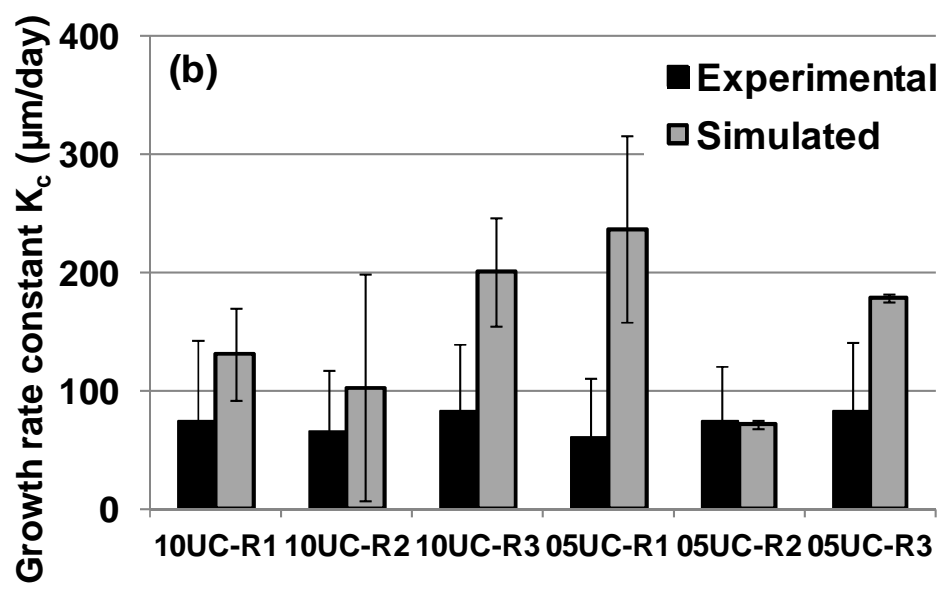

640 Fig. 11 Comparison between the experimental and the calculated growth rate constants 641 for carbonated (a) and uncarbonated (b) mortars 